恶

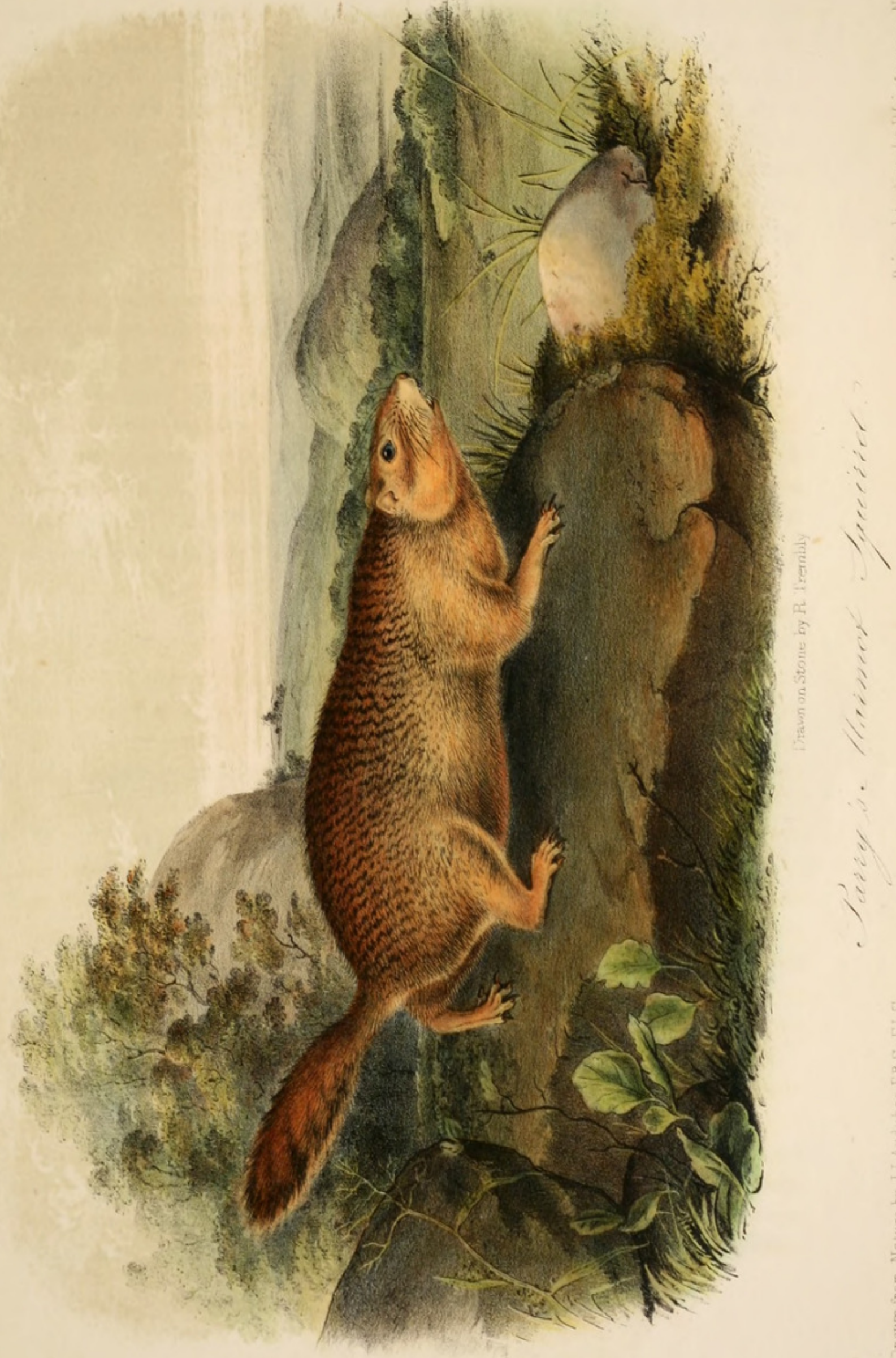



In referring again to the dentition of these allied genera, we may remark that the anterior molar of the upper jaw, which is deciduous and falls out at an early period in most species of true squirrels, remains permanently in all species of the genus Tamis and is smaller than in the Spermophiles. These genera differ also in the form and length of their claws. The long nails of the latter, the second claw, moreover, being longest, places them near the marmots; while the shorter, weaker, and more arched nails of the ground squirrels, in which the third claw, besides, is the longest, approximates them more nearly to the true squirrels.

The clucking notes of the chipping squirrels are replaced in the marmot-squirrels by the shrill whistling or chattering sounds emitted by the marmots.

The generic appellation Spermophilus, is derived from the Greek

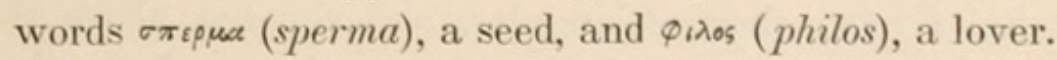

There are now twelve species of this genus known as existing in North America, and three in Europe, and a few are set down as belonging to Asia and Africa. Some of the latter may, however, after more careful examination, be found to belong to the genus Австомуs.

\title{
SPERMOPHILUS PARRYI.-RICHARDSON.
}

\author{
Parry's Marmot-Squirrel.-Parry's Spermophile.
}

PLATE IX.-MALE.

S. flavo-cinereus, supra albo variegatus, genis, lateribus, ventre, pedibusque flavis; fronte aureo, pilis ex flavo et nigro; ad radices flavis, apice nigris.

CHARACTERS.

General colour, yellowish-gray; upper parts, mottled with white ; cheeks, sides, under parts of the body, and feet, yellow; fore-part of the head, deep rich yellow; the hairs varied with yellow and black; at the roots chiefly deep yellow, and at the points principally black 
SYNONYMES.

Ground-squirrel, Hearne's Journey, pp. 141 and 386.

Quebec Marmot, Forster, Phil. Trans., vol. lxii. p. 378.

Arctomys Alpina, Parry, Second Voyage, p. 61, narrative.

Arctomys Parry, Richardson, Parry's Second Voyage, App., p. 316.

Arctomys (Spermophilus) Parryi, Rich., Fauna Boreali Americana, p. 158, pl. 10.

Seek-Seek, Esquimaux,-Thoe-Thiay Rock-Badger, Chipewyans, Rich.

\section{DESCRIPTION.}

This marmot-squirrel, although far from being as thick and heavy as the Maryland marmot, is not nearly so light and graceful as most of the other species of this genus, especially Sp. Douglassii; and in form resembles the marmots more than it does the ground squirrels. The forehead is arched, the nose rather short, thick, and closely covered with short hair; ears, short, triangular, and situated above the auditory opening; eyes, prominent, and of moderate size; a few rather slender hairs over the eyes; along the cheeks are whiskers, arranged in five rows. Cheek-pouches, of medium dimensions, and opening into the mouth immediately behind the molars.

Legs and feet rather short and stout; toes well separated; nails long; feet covered with short hairs ; palms of the fore-feet naked ; soles of hindfeet for half an inch next the heel clothed with hair, the remainder naked. Tail, rather flat, rounded at base, hairs becoming longer towards the extremity; sub-distichous. The under fur on every part of the body, soft, glossy, and of a silky appearance.

COLOur.

Hairs of the back, black at the roots, annulated above with black, nearer the tips yellowish-white or white; extreme tips black.

The longest hairs black; the under, black at the base, then whitish, and shaded into brown at the points. The whole upper surface is irregularly and thickly spotted with white; the spots confluent, especially over the shoulders; on the belly the under-fur is abundant, very soft and silky; grayish-black at the base, and yellowish-white at the tips; the visible portion of the longer hairs, deep yellow on the sides of the body, and paler yellow on the belly. Feet, yellow; hairs on the toes a pale yellow ; claws blackish-brown; the hinder half of the tarsus covered beneath with brownish hairs; upper surface of the head, as far back as the eyes, of a deep rich yellow ; around the eyes whitish; cheeks yellow ; chin, throat, and sides of the muzzle, yellowish-white; tail, at base, coloured like the body; in the middle, the hairs are yellowish, with two 
rings or bars of black at the tips. The hairs on the under surface of the tail are chiefly of a rusty or brownish-red colour; moustaches black.

DIMENSIONS.

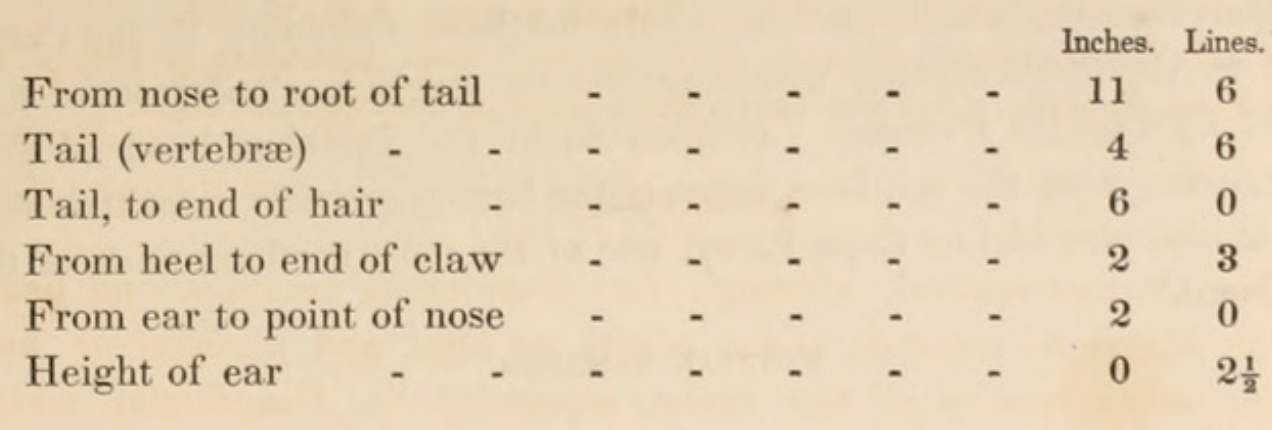

HABITS,

The only account we have of this handsome spermophile is that given by its talented discoverer, who says of it,-

"It is found generally in stony districts, but seems to delight chiefly in sandy hillocks amongst rocks, where burrows, inhabited by different individuals, may be often observed crowded together. One of the society is generally observed sitting erect on the summit of the hillocks, whilst the others are feeding in the neigbourhood. Upon the approach of danger, he gives the alarm, and they instantly betake themselves to their holes, remaining chattering, however, at the entrance until the advance of the enemy obliges them to retire to the bottom. When their retreat is cut off, they become much terrified, and seeking shelter in the first crevice that offers, they not unfrequently succeed only in hiding the head and fore-part of the body, whilst the projecting tail is, as usual with them when under the influence of terror, spread out flat on the rock. Their cry in this season of distress strongly resembles the loud alarm of the Hudson's Bay squirrel, and is not very unlike the sound of a watchman's rattle. The Esquimaux name of this animal, Seek-Seek, is an attempt to express this sound. According to Hearne, they are easily tamed, and are very cleanly and playful in a domestic state. They never come abroad during the winter. Their food appears to be entirely vegetable; their pouches being generally observed to be filled, according to the season, with tender shoots of herbaceous plants, berries of the Alpine arbutus, and of other trailing shrubs, or the seeds of bents, grasses, and leguminous plants. They produce about seven young at a time."

Captain Ross mentions that some of the dresses of the Esquimaux at Repulse Bay, were made of the skins of this species; these people also informed him that it was very abundant in that inhospitable region. 
GEOGRAPHICAL DISTRIBUTION.

According to Dr. Richardson, "this spermophile inhabits the barren grounds skirting the sea-coast, from Churchill, in Hudson's Bay, round by Melville's Peninsula, and the whole northern extremity of the Continent to Behring's Straits, where specimens precisely similar were procured by Captain Beschey. It abounds in the neighbourhood of Fort Enterprise, near the southern verge of the barren grounds in latitude $65^{\circ}$, and is also plentiful on Cape Parry, one of the most northern parts of the continent."

\section{GENERAL REMARKS.}

Our description of this rare animal was drawn up from a specimen deposited by Dr. Richardson in the museum of the Zoological Society of London, which was said to have been the identical skin from which his description was taken.

We possess another specimen, presented to us by Dr. Richardson, which is a little longer in the body and shorter in the tail than the one we have just spoken of; the body being $12 \frac{1}{2}$ inches in length, and the tail (vertebræ) $3 \frac{1}{2}$ inches, including fur 5 inches. The forehead and buttocks of this specimen are reddish-brown. 


\section{$2 \mathrm{BHL}$ Biodiversity Heritage Library}

Audubon, John James and Bachman, John. 1851. "Spermophilus Parryl, Parry's Marmot Squirrel -Parry's Spermophile [PI. IX, male]." The quadrupeds of North America 1, 77-80. https://doi.org/10.5962/p.322584.

View This Item Online: https://www.biodiversitylibrary.org/item/108513

DOI: https://doi.org/10.5962/p.322584

Permalink: https://www.biodiversitylibrary.org/partpdf/322584

\section{Holding Institution}

Duke University Libraries (archive.org)

\section{Sponsored by}

Duke University Libraries

\section{Copyright \& Reuse}

Copyright Status: Not provided. Contact Holding Institution to verify copyright status.

This document was created from content at the Biodiversity Heritage Library, the world's largest open access digital library for biodiversity literature and archives. Visit BHL at https://www.biodiversitylibrary.org. 